\title{
EKSPERIMENTASI MODEL PEMBELAJARAN INKUIRI TERBIMBING TERHADAP PEMAHAMAN KONSEP SISWA SMA DITINJAU DARI MOTIVASI BELAJAR
}

\author{
Ulfah Nur Arifin \\ Program Studi Pendidikan Matematika, FKIP, UMMI
}

Ulfahnuaraifin@gmail.com

\begin{abstract}
ABSTRAK
Tujuan dari penelitian ini adalah untuk mengetahui pemahaman konsep siswa yang mendapatkan pembelajaran menggunakan model pembelajaran inkuiri terbimbing lebih baik dari model pembelajaran langsung yang ditinjau dari motivasi belajar siswa kelas X IPA 4 dan X IPA 6 SMA Negeri 4 Kota Sukabumi yang berjumlah 78 siswa. Pembelajaran inkuiri yang dilakukan terdiri dari penyajian masalah, pengumpulan data verifikasi, pengumpulan data eksperimen, organisasi data dan formulasi kesimpulan, dan analisis inkuiri. Kecenderungan siswa menghafal rumus dan pembelajaran yang kurang melibatkan siswa menjadi salah satu penyebab masih rendahnya hasil belajar siswa. Pembelajaran inkuiri melatih siswa untuk menemukan sendiri konsep matematika dan melibatkan partisipasi siswa secara optimal. Metode pengumpulan data dilakukan melalui observasi, dokumentasi dan tes. Penelitian ini menggunakan metode penelitian semu (quasi eksperimental research). Hasil penelitian menunjukkan bahwa motivasi tidak berpengaruh kepada pemahaman konsep siswa dan pemahaman konsep siswa dengan menggunakan model pembelajaran inkuiri terbimbing lebih baik dari pada model pembelajaran langsung.
\end{abstract}

Kata Kunci: Pemahaman Konsep, Inkuiri Terbimbing, Motivasi.

\section{PENDAHULUAN}

Pendidikan memegang peranan penting dalam mempersiapkan sumberdaya manusia yang berkualitas agar mampu berkompetensi dalam perkembangan ilmu pengetahuan dan teknologi. Oleh karena itu pendidikan harus dilaksanakan dengan sebaik-baiknya untuk memperoleh hasil yang maksimal. Salah satunya dengan memaksimalkan proses pembelajaran di sekolah. Indonesia masih rendah dalam pemahaman konsep, menurut laporan TIMSS (Trends International Mathematics and Science Study) (2011: 2) hal ini disebabkan beberapa faktor penyebab seperti kebiasaan, minat, motivasi, dan budaya baca yang masih rendah. Pemahaman konsep sangat diperlukan bagi siswa yang sudah mengalami proses belajar. Pemahaman konsep yang dimiliki oleh siswa dapat digunakan untuk menyelesaikan suatu permasalahan yang ada kaitan dengan konsep yang dimiliki. Dalam pemahaman konsep siswa tidak hanya sebatas mengenal tetapi siswa harus dapat menghubungkan satu konsep dengan konsep lain. Seperti yang diungkapkan oleh Bloom, dalam (Lestari dan Yudhanegara, 2015: 6) "pemahaman diartikan sebagai kemampuan untuk menyerap arti dari materi atau bahan yang dipelajari”. Pada proses pembelajaran di kelas mayoritas siswa diarahkan hanya pada kemampuan cara menggunakan rumus, menghafal rumus, namun jarang diajarkan untuk menganalisis. Akibatnya pada saat siswa diberi soal yang berbeda dengan soal latihannya, mereka akan membuat kekeliruan. Karena siswa tidak memahami konsep dasar dari materi yang mereka pelajari.

Berdasarkan hasil wawancara dengan salah satu guru matematika di SMA Negeri 4 Kota Sukabumi, bahwa salah satu materi yang dianggap sulit dipahami siswa adalah trigonometri karena banyak menggunakan konsep yang tidak nyata. ". Hal ini dapat dilihat dari nilai ulangan siswa yang mayoritas belum mencapai Kriteria Ketuntasan Minimun (KKM), yaitu dengan standar nilai yang harus dicapai 75 . Persentase ketuntasan siswa yang sudah mencapai KKM sebanyak $25 \%$ dan $75 \%$ dibawah KKM. Pada pokok bahasan trigonometri siswa cenderung hanya menghafal rumus dan kurang termotivasi untuk memahami konsep trigonometri. Sebagian siswa masih belum mampu untuk menyelesaikan soal aplikasi dalam kehidupan seharihari yang menggunakan aturan sinus dan cosinus. Hal ini dikarenakan siswa tidak mampu menganalisis soal dan menghubungkan dengan bentuk perbandingan dalam segitiga siku-siku sehingga kesulitan menggunakan rumus trigonometri.

Sesuai dengan penelitian (Rahardjo, dkk. 2016 : 47) pada kenyataannya masih banyak siswa yang kesulitan dalam memahami konsep matematika. Bahkan kebanyakan siswa tidak dapat mendefinisikan kembali bahan pelajaran matematika dengan bahasa mereka 
sendiri. Salah satu penyebab rendahnya pemahaman konsep siswa dikarenakan belum optimal dalam proses pembelajaran matematika di sekolah. Hal ini sejalan dengan penelitian yang dilakukan oleh (Dahlan, 2004) hasil penelitiannya mengungkapkan bahwa dalam pembelajaran matematika di sekolah, siswa cenderung pasif, berpusat pada guru (teacher oriented), chalk and talk. Pada proses pembelajaran di sekolah guru dituntut untuk tidak memberikan konsep konsep materi pembelajaran secara langsung, tetapi siswa harus dibimbing oleh guru untuk mencari dan mengetahui proses terbentuknya sebuah konsep atau rumus, yang nantinya dapat digunakan untuk menyelesaikan soal-soal latihan yang diberikan. Untuk itu, seorang guru harus mampu memilih sebuah model atau pendekatan pembelajaran yang dapat meningkatkan pemahaman konsep siswa pada mata pelajaran matematika, agar siswa lebih mudah memahami materi yang dipelajarinya. Salah satu upaya untuk menyelesaikan masalah tersebut adalah penerapan pembelajaran yang melatih siswa belajar untuk menemukan sendiri konsep matematika dan melibatkan partisipasi siswa secara optimal dalam proses pembelajaran. Pemahaman konsep sangat penting untuk belajar matematika secara bermakna, seperti yang dinyatakan Zulkardi dalam (Rahardjo, dkk. 2016 : 46) bahwa matematika menekankan pada konsep. Pemahaman konsep matematika siswa dapat dicapai dengan menerapkan model pembelajaran inkuiri. Dengan pembelajaran ini akan melatih siswa menemukan sendiri konsep matematika dan melibatkan siswa secara optimal. Model pembelajaran inkuiri merupakan pendekatan pembelajaran di mana siswa didorong untuk belajar melalui keterlibatan aktif mereka sendiri dengan konsep-konsep dan prinsip-prinsip (Putra, 2012: 8). Model pembelajaran inkuiri terbimbing merupakan model pembelajaran inkuiri yang diorganisasikan lebih terstruktur, dimana guru mengendalikan keseluruhan proses interaksi dan menjelaskan prosedur penelitian yang harus dilakukan oleh siswa. Siswa memperoleh pedoman sesuai dengan yang dibutuhkan. Selain memilih sebuah model atau pendekatan yang cocok untuk siswa, faktor motivasi sangat penting dalam menentukan efektivitas pembelajaran dan pencapaian siswa dalam belajar. Hamalik (2014: 186) mendefinisikan "Motivasi adalah suatu perubahan energi dalam pribadi seseorang yang ditandai dengan timbulnya afektif dan reaksi untuk mencapai tujuan. Hal ini sesuai dengan pendapat ahli psikologi dalam Dimyati dan
Mudjiono (2013: 80) yang menyatakan kekuatan mental yang mendorong terjadinya belajar tersebut sebagai motivasi belajar. Siswa belajar karena didorong oleh kekuatan mentalnya. Kekuatan mental itu berupa keinginan, perhatian, kemauan, atau cita-cita. Kekuatan mental tersebut dapat tergolong rendah atau tinggi. Rumusan masalah penelitian ini adalah sebagai berikut: 1) Apakah pemahaman konsep siswa yang mendapatkan pembelajaran menggunakan model pembelajaran inkuiri terbimbing lebih baik dari model pembelajaran langsung? 2) Apakah siswa yang memiliki motivasi tinggi lebih baik dalam pencapaian pemahaman konsep dibandingkan siswa yang memiliki motivasi rendah? 3) Apakah pada masing-masing model pembelajaran, siswa yang memiliki motivasi belajar tinggi lebih baik dalam pemahaman konsep dibandingkan dengan siswa yang memiliki motivasi belajar rendah? 3) Apakah pada masing-masing tingkat motivasi belajar siswa, Model Pembelajaran Inkuiri Terbimbing lebih baik dalam pemahaman konsep dibandingkan dengan model pembelajaran langsung?

Tujuan penelitian ini adalah sebagai berikut: 1) Untuk mengetahui apakah pemahaman konsep siswa yang mendapatkan pembelajaran menggunakan model pembelajaran inkuiri terbimbing lebih baik dari model pembelajaran langsung. 2) Untuk mengetahui apakah pencapaian kemampuan pemahaman konsep siswa yang memiliki motivasi tinggi lebih baik dibanding dengan siswa yang memiliki motivasi rendah. 3) Untuk mengetahui pada masing-masing model pembelajaran, manakah yang lebih baik dalam pemahaman konsep siswa antara motivasi belajar tinggi dan motivasi belajar rendah. 4) Untuk mengetahui pada masing-masing tingkat motivasi belajar, manakah yang lebih baik dalam pemahaman konsep siswa antara Model Pembelajaran Inkuiri Terbimbing dan pembelajaran langsung.

Manfaat penelitian ini hasil penelitiannya mengenai model pembelajaran Inkuiri Terbimbing terhadap pemahaman konsep siswa ditinjau dari motivasi belajar dapat menjadi bahan dasar untuk memberikan solusi dalam mengatasi rendahnya pemahaman konsep pada materi Trigonometri.

\section{METODE}

Desain penelitian yang digunakan dalam penelitian ini adalah post- test Only Control Group Design. Secara singkat desain penelitian ini menggunakan desain factorial 2 x 2 dapat digambarkan sebagai berikut: 
Tabel 1

Desain faktorial 2x2

\begin{tabular}{|c|c|c|c|}
\hline \multirow{2}{*}{\multicolumn{2}{|c|}{ Motiv }} & \multicolumn{2}{|c|}{ Model Pembelajaran } \\
\hline & & $\begin{array}{l}\text { Inkuiri Terbimbing } \\
\qquad\left(\mathrm{A}_{1}\right)\end{array}$ & $\begin{array}{c}\text { Pembelajar } \\
\text { an } \\
\text { Langsung } \\
\left(\mathrm{A}_{2}\right)\end{array}$ \\
\hline $\begin{array}{l}\text { Moti } \\
\text { vasi }\end{array}$ & $\begin{array}{c}\text { Tinggi } \\
\left(\mathrm{B}_{1}\right)\end{array}$ & $\mathrm{A}_{1} \mathrm{~B}_{1}$ & $\mathrm{~A}_{1} \mathrm{~B}_{2}$ \\
\hline Siswa & $\begin{array}{c}\text { Rendah } \\
\left(\mathrm{B}_{2}\right)\end{array}$ & $\overline{A_{2} B_{1}}$ & $\mathrm{~A}_{2} \mathrm{~B}_{2}$ \\
\hline
\end{tabular}

Keterangan:

$$
\begin{array}{ll}
\mathrm{A}_{1} & =\text { Model pembelajaran Inkuiri terbimbing. } \\
\mathrm{A}_{2} & =\text { Model pembelajaran langsung. } \\
\mathrm{B}_{1} & =\text { Motivasi tinggi. } \\
\mathrm{B}_{2} & =\text { Motivasi rendah. }
\end{array}
$$

$\mathrm{A}_{1} \mathrm{~B}_{1}=$ Kelompok siswa yang memiliki motivasi belajar tinggi dengan diberi perlakuan model pembelajaran Inkuiri terbimbing.

$\mathrm{A}_{2} \mathrm{~B}_{1} \quad=$ Kelompok siswa yang memiliki motivasi belajar rendah dengan diberi perlakuan model pembelajaran Inkuiri terbimbing.

$\mathrm{A}_{1} \mathrm{~B}_{2}=$ Kelompok siswa yang memiliki motivasi belajar tinggi dengan diberi perlakuan model pembelajaran langsung.

$\mathrm{A}_{2} \mathrm{~B}_{2}=$ Kelompok siswa yang memiliki motivasi belajar rendah dengan diberi perlakuan model pembelajaran langsung. Kedua kelas diberikan perlakuan yang berbeda. Perlakuan yang dilakukan dalam penelitian ini adalah Pembelajaran Inkuiri Terbimbing untuk kelas eksperimen, dan model pembelajaran langsung untuk kelas kontrol. Kemudian kedua kelas diberikn Post-test untuk mengetahui kemampuan pemahaman konsep. Populasi dalam penelitian ini adalah seluruh siswa yang kelas $\mathrm{X}$ sebanyak 6 kelas yang berjumlah 252 siswa di SMA Negeri 4 Kota Sukabumi tahun ajaran 2016/2017. Penelitian ini tidak memiliki semua subjek dalam populasi. Peneliti hanya mengambil sebagian subjek atau sering disebut pengambilan sampel. Diharapkan hasil penelitian yang didapat sudah dapat menggambarkan populasi yang bersangkutan. Sesuai dengan pendapat Sugiyono (2015:118) "Sampel adalah bagian dari jumlah dan karakteristik yang dimiliki oleh populasi tersebut".

Teknik pengambilan sampel yang dilakukan dalam penelitian ini adalah cluster random sampling, yaitu dengan cara memandang populasi sebagai kelompok-kelompok. Kelas dipandang sebagai satuan kelompok belajar yang kemudian tiap kelas diberi nama sesuai nama kelasnya untuk diacak dengan undian. Undian tersebut dilaksanakan satu tahap dengan dua kali pengambilan. Nomor kelas yang diambil pertama sebagai eksperimen dan nomor kelas yang diambil berikutnya adalah sebagai kelas kontrol. Pengambilan sampel secara acak pada populasi dimaksudkan agar sampel pada populasi dapat terwakili oleh dua sampel yang terpilih, yaitu X IPA 4 yang berjumlah 37 orang sebagai kelas eksperimen dan X IPA 6 yang berjumlah 41 orang sebagai kelas kontrol.

Teknik pengumpulan data pada penelitian ini ada 3 macam yaitu 1) Metode Dokumentasi 2) Metode Observasi 3) Metode Tes.

\section{HASIL DAN PEMBAHASAN}

\section{Deskripsi Hasil Kemampuan Akhir Pemahaman Konsep}

Data kemampuan awal pemahaman konsep siswa diperoleh dari hasil UTS. Data awal ini digunakana untuk mengetahui kemampuan pemahaman konsep siswa dari kedua kelas yang diambil.

Tabel 2

Normalitas distribusi data kemampuan awal kelas eksperimen dan kelas kontrol

\begin{tabular}{|l|c|c|c|c|}
\hline \multicolumn{1}{|c|}{ Kelas } & \multirow{2}{*}{$\mathbf{N}$} & \multicolumn{2}{c|}{ Nilai } & \multirow{2}{*}{$\begin{array}{c}\text { Keputusan } \\
\text { Uji }\end{array}$} \\
\cline { 3 - 4 } & & $\mathrm{L}_{\text {hitung }}$ & $\mathrm{L}_{\text {tabel }}$ & Eksperimen \\
\hline Kontrol & 47 & 0,11 & 0,145 & $\mathrm{H}_{0}$ diterima \\
\hline Kon & 41 & 0,11 & 0,138 & $\mathrm{H}_{0}$ diterima \\
\hline
\end{tabular}

Berdasarkan dari hasil tabel diatas, menunjukkan bahwa $\mathrm{L}_{\text {maks }}$ untuk kelas eksperimen dan kontrol adalah 0,09 . Nilai $\mathrm{L}_{\text {maks }}$ tersebut tidak berada pada daerah kritis $\left\{\mathrm{L} \mid \mathrm{L}>\mathrm{L}_{\alpha: n}\right\}$ karena $\mathrm{L}_{\text {maks }}$ kurang dari $\mathrm{L}_{\text {tabel. }}$ Oleh karena itu berdasarkan pengambilan keputusan maka $\mathrm{H}_{0}$ diterima. Hal ini berarti sampel berasal dari populasi yang berdistribusi normal.

\section{Tabel 3}

Homogenitas dua varian data kemampuan awal kelas eksperimen dan kelas kontrol

\begin{tabular}{ccc}
\hline F hitung & Ftabel $_{1}$ & Keputusan Uji \\
\hline $\mathbf{0 , 0 0 0 5}$ & 3,84 & $\mathrm{H}_{0}$ diterima \\
\hline
\end{tabular}

Berdasarkan dari hasil uji homogenitas pada tabel diatas dengan taraf signifikansi 0,05. Menunjukkan bahwa $\mathrm{X}^{2}$ hitung yaitu 0,000555 kurang dari $\mathrm{X}^{2}$ yaitu 0,84 Oleh karena itu $\mathrm{X}_{\text {tabel }}^{2}$ tidak berada pada daerah kritis \{ $\mathrm{X}^{2} \mid \mathrm{X}^{2}>\mathrm{X}^{2}$ a:k-1 $\}$ maka berdasarkan pengambilan keputusan $\mathrm{H}_{0}$ diterima. Maka dengan demikian maka 
dapat disimpulkan bahwa sampel mempunyai variansi yang sama.

Berdasarkan hasil uji normalitas dan homogenitas yang telah dilakukan, diperoleh data yang berdistribusi normal dan homogen sehingga dapat dilanjutkan uji keseimbangan dengan menggunakan uji t dua pihak. Uji keseimbangan dilakukan untuk mengetahui kedua sampel mempunyai kemampuan awal yang sama atau tidak, dengan taraf signifikansi 0,05.

Setelah dilakukan pengolahan data, data dapat dilihat pada tabel sebagai berikut:

\section{Tabel 4}

Uji t kemampuan awal kelas eksperimen dan kelas kontrol

\begin{tabular}{ccc}
\hline thitung & ttabel & Keputusan $\mathbf{U j i}$ \\
\hline $\mathbf{0 , 2 6 8 1}$ & 1,66 & $\mathrm{H}_{0}$ diterima \\
\hline
\end{tabular}

Berdasarkan hasil uji keseimbangan diatas, bahwa kedua sampel mempunyai nilai $t_{\text {hitung }}$ 0,2681 dan dengan nilai $t_{\text {tabel }}$ 1,66 Karena nilai $t_{\text {hitung }}$ kurang dari $t_{\text {tabel }}$ maka $t_{\text {hitung }}$ tidak berada pada daerah kritis $\left\{t \mid t<-t_{\frac{a}{2}}\right.$ atau $t>$ $\left.t_{\frac{t}{2}}\right\}$. Oleh karena itu berdasarkan pengambilan keputusan maka $\mathrm{H}_{0}$ diterima. Dengan demikian kedua sampel mempunyai kemampuan yang sama. Perhitungan selengkapnya pada lampiran.

\section{Deskripsi Hasil Akhir Kemampuan Awal Pemahaman Konsep (Posttest)}

Data ini diperoleh dari hasil posttest kemampuan pemahaman konsep siswa setelah mendapatkan perlakuan, kelas eksperimen dengan menggunakan model pembelajaran inkuiri terbimbing dan kelas kontrol dengan model pembelajaran langsung.

Uji normalitas pada penelitian ini menggunakan metode Liliefors dengan taraf signifikan 0,05. Pada penelitian ini uji normalitas pada tes kemampuan pemahaman konsep kelas eksperimen $\left(\mathrm{A}_{1}\right)$, Kelas kontrol $\left(\mathrm{A}_{2}\right)$, motivasi tinggi $\left(B_{1}\right)$, dan motivasi rendah $\left(B_{2}\right)$. Perhitungan hasil uji normalitas sebagai berikut.

\section{Tabel 5}

Uji normalitas hasil penelitian

\begin{tabular}{ccccccccc}
\hline $\begin{array}{c}\text { Kel } \\
\text { omp } \\
\text { ok }\end{array}$ & $\mathbf{n}$ & $\bar{X}$ & $\begin{array}{c}\text { Mi } \\
\mathbf{n}\end{array}$ & Max & $\mathbf{S}$ & $\begin{array}{c}\text { Lhitun } \\
\mathbf{g}\end{array}$ & Ltabel & $\begin{array}{c}\text { Keputusa } \\
\mathbf{n} \text { uji }\end{array}$ \\
\hline$\left(\mathbf{A}_{1}\right)$ & 37 & 67,405 & 39 & 92 & 14,0049 & 0,12 & 0,145 & $\begin{array}{c}\mathrm{H}_{0} \\
\text { diterima }\end{array}$ \\
$\left(\mathbf{A}_{2}\right)$ & 41 & 63,2195 & 39 & 89 & 13,091 & 0,07 & 0,138 & $\begin{array}{c}\mathrm{H}_{0} \\
\text { diterima }\end{array}$ \\
$\left(\mathbf{B}_{1}\right)$ & 56 & 66,4286 & 39 & 92 & 13,3565 & 0,09 & 0,118 & $\begin{array}{c}\mathrm{H}_{0} \\
\text { diterima } \\
\mathbf{H}_{0}\end{array}$ \\
$\left(\mathbf{B}_{2}\right)$ & 22 & 61,9545 & 39 & 89 & 14,1606 & 0,1 & 0,19 & $\begin{array}{c}\mathrm{H}_{0} \\
\text { diterima }\end{array}$ \\
\hline \multicolumn{5}{c}{ Berdasarkan } & hasil perhitungan & diatas
\end{tabular}

menunjukkan bahwa $L_{\text {hitung }}$ pada setiap kelompok kurang dari $\mathrm{L}_{\text {tabel}}$, maka $\mathrm{L}_{\text {hitung }}$ dalam setiap kelompok tidak berada pada daerah kritis $\left\{\mathrm{L} \mid \mathrm{L}>L_{a: n}\right\}$. Maka berdasarkan keputusan $\mathrm{H}_{0}$ diterima, dengan demikian sampel berasal dari populasi normal. Data selengkapnya dapat dilihat pada lampiran.

Tabel 6

Uji Homogenitas hasil penelitian

\begin{tabular}{|c|c|c|c|}
\hline & $\mathbf{F}_{\text {hitung }}$ & $F_{\text {tabel }}$ & Keputusan Uji \\
\hline Model & 2,7436 & 3,84 & $\mathrm{H}_{0}$ diterima \\
\hline Motivasi & 1,355 & 3,84 & $\mathrm{H}_{0}$ diterima \\
\hline
\end{tabular}

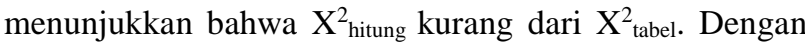
demikian berdasarkan pengambilan keputusan uji $\mathrm{H}_{0}$ diterima. Karena $\mathrm{H}_{0}$ diterima maka dapat disimpulkan bahwa sampel mempunyai variansi yang sama.

Hasil perhitungan uji hipotesis ini menggunakan uji analisis variansi dua jalan dengan sel tak sama dengan taraf signifikansi 0,05 . Hasil ringkasan perhitungan sebagai berikut.

Tabel 7

Rangkuman ringkasan analisis variansi dua jalan sel tak sama

\begin{tabular}{ccccccc}
\hline $\begin{array}{c}\text { Sumb } \\
\text { er }\end{array}$ & JK & $\begin{array}{c}\text { D } \\
\text { K }\end{array}$ & RK & Fobs $_{n}$ & Fo & P \\
\hline $\begin{array}{c}\text { Mode } \\
\text { l (A) }\end{array}$ & 449,67 & 1 & 449,67 & 6,85 & 3,97 & $<0,0$ \\
Moti & 24,955 & 1 & 24,955 & 0,38 & 3,97 & $>0,0$ \\
vasi \\
(B)
\end{tabular}


Berdasarkan hasil perhitungan uji analisis anava dua jalan sel tak sama menunjukkan bahwa

1) Nilai $F_{\text {obs }}$ untuk model pembelajaran yaitu 6,85 dengan $F_{\text {obs }}$ tidak berada pada daerah kritis, maka berdasarkan keputusan uji $\mathrm{H}_{0}$ ditolak. Karean $\mathrm{H}_{0}$ ditolak maka dapat disimpulkan bahwa model pembelajaran berpengaruh pada pemahaman konsep siswa.

2) Nilai $F_{\text {obs }}$ untuk motivasi siswa yaitu 0,38 dengan $F_{\text {obs }}$ berada pada daerah kritis, maka berdasarkan keputusan uji $\mathrm{H}_{0}$ diterima. Karena $\mathrm{H}_{0}$ diterima maka dapat disimpulkan bahwa motivasi tidak berpengaruh pada pemahaman konsep siswa.

3) Nilai $F_{\text {obs }}$ untuk interaksi model pembelajaran dan motivasi yaitu 1,08 dengan $\mathrm{F}_{\mathrm{obs}}$ tidak berada pada daerah kritis, maka berdasarkan keputusan uji $\mathrm{H}_{0}$ diterima. Karena $\mathrm{H}_{0}$ diterima maka dapat disimpulkan bahwa tidak ada interaksi antara model pembelajaran dan motivasi terhadap pemahaman konsep.

Karena tidak ada interaksi antara model pembelajaran dengan motivasi siswa maka tidak dilakukan uji komparansi ganda atau uji pasca anava, tetapi untuk melihat model dan motivasi yang lebih baik dilihat dari rataan marginalnya. Hasil perhitungan rataan antar sel sebagai berikut:

\section{Tabel 8}

\section{Rataan antar Sel}

Berdasarkan hasil perhitungan analisis variansi dua jalur sel tak sama untuk hipotessis pertama pada model pembelajaran menunjukkan pemahaman konsep siswa yang mendapat pembelajaran menggunakan model inkuiri terbimbing lebih baik dari model pembelajaran langsung. Keberhasilan proses pembelajaran siswa ditentukan oleh beberapa faktor yaitu dantaranya model pembelajaran yang dipakai oleh guru pada saat proses pembelajaran. banyaknya model pembelajaran pada saat ini yang sedang berkembang, dan itu bisa menjadi salah satu acuan bagi guru untuk menerapkan model pembelajaran pada saat pembelajaran berlangsung dan disesuaikan dengan materi yang akan diajarkan. Menurut Dahlan dalam (Sutikno, 2014: 57) menyebutkan "Karena model pembelajaran merupakan suatu rencana atau pola yang digunakan dalam menyusun kurikulum, mengatur materi pelajaran dan memberi petunjuk kepada pengajar di kelas dalam setting pengajaran atau setting lainnya".

Pada peneitian ini didapatkan bahwa model pembelajaran Inkuiri terbimbing lebih baik dari model pembelajaran langsung, hal ini bisa dilihat pada hasil rataan marginal. Pada model pembelajaran inkuiri terbimbing, pada model pembelajaran Inkuiri terbimbing materi yang disajikan guru bukan begitu saja diberikan dan diterima oleh siswa, tapi siswa diusahakan sedemikan rupa sehingga mereka memperoleh berbagai pengalaman dalam rangka menemukan sendiri konsepkonsep yang direncanakan oleh guru (Wahyudin\& Sutikno, 2010: 6). Maka dalam penelitian ini siswa belajar secara kelompok dengan teman sebangkunya serta menyelesaikan masalah dalam bentuk Lembar Aktivitas Siswa (LAS) yang diberikan oleh guru.

Hasil penelitian ini sesuai dengan penelitian Penelitian yang dilakukan Chodijah, dkk (2012) menunjukkan bahwa perangkat pembelajaran yang dikembangkan dengan menggunakan model Inkuiri Terbimbing sangat valid, sangat praktis, dan efektif. Serta seperti penelitian yang dilakukan oleh Kurniawati, dkk (2014) menunjukkan bahwa terdapat perbedaan penguasaan konsep siswa yang menggunakan pembelajaran inkuiri terbimbing, pembelajaran inkuiri terbimbing dan pembelajaran konvensional, penguasaan konsep siswa yang belajar dengan pembelajaran inkuiri terbimbing lebih tinggi daripada pembelajaran konvensional. Model pembelajaran yang digunakan dalam peneltian ini yaitu Inkuiri terbimbing dan langsung. Model Inkuiri terbimbing lebih baik dari model

\begin{tabular}{|c|c|c|c|}
\hline \multirow[t]{2}{*}{ Motivasi } & \multicolumn{2}{|c|}{ Model Pembelajaran } & \multirow{2}{*}{$\begin{array}{c}\text { Rataan } \\
\text { Marginal }\end{array}$} \\
\hline & $\begin{array}{c}\text { Inkuiri } \\
\text { Terbimbing }\end{array}$ & Langsung & \\
\hline Tinggi & 67,444 & 64,207 & 65,825 \\
\hline Rendah & 68,300 & 60,833 & 64,566 \\
\hline $\begin{array}{c}\text { Rataan } \\
\text { Marginal }\end{array}$ & 67,872 & 62,52 & \\
\hline
\end{tabular}

pembelajaran langsung dilihat dari rataan marginalnya jika dibandingkan dengan nilai rataan marginal model pembelajaran langsung, maka dalam penelitian ini model pembelajaran Inkuiri terbimbing lebih efektif pada masing-masing motivasi siswa.

Berdasarkan hasil perhitungan analisis variansi dua jalur sel tak sama hipotesis kedua pada motivasi menunjukkan bahwa motivasi tidak berpengaruh pada pemahaman konsep siswa, baik dalam pembelajaran menggunakan model pembelajaran Inkuiri terbimbing ataupun dengan menggunakan model pembelajaran langsung. Walaupun dalam hasil angket menunjukkan bahwa siswa yang motivasi tinggi lebih banyak dari pada motivasi rendah. Faktor-faktor yang mempengaruhi proses pembelajaran bergerak secara bersamaan, maka 
dalam hal ini akan mempengaruhi motivasi siswa dalam belajar pada siswa yang memiliki motivasi tinggi dan sisiwa yang memiliki motivasi rendah. Faktor pengaruh yang lain merupakan bagian dari motivasi ekstrinsik. Karena menurut (Suryabrata, 2012: 72) menyatakan "motivasi ekstrinsik yaitu motivasi yang berfungsi karena adanya perangsang dari luar". Berdasarkan temuan hasil penelitian ini siswa yang memiliki motivasi tinggi tidak terbukti lebih baik dari siswa yang memiliki motivasi rendah pada pemahaman konsep. Hal ini disebabkan karena pada saat proses pembelajaran siswa yang telah menguasai materi akan lebih akan dalam pembelajaran dan siswa yang merasa takut untuk bertanya kepada guru. Motivasi siswa pada saat mengerjakan soal tes dipengaruhi oleh kondisi siswa, lingkungan, emosi siswa dan suasana kelas. Hal ini sesuai dengan skripsi Trisnanto (2009) yang menyatakan bahwa“ tidak ada pengaruh motivasi belajar tinggi dan motivasi belajar rendah terhadap prestasi belajar".

Berdasarkan hasil perhitungan analisis variansi dua jalur sel tak sama hipotesis ketiga pada interaksi motivasi dan model pembelajaran, bahwa tidak terdapat interaksi antara model pembelajaran dengan motivasi pada pemahaman konsep siswa. Maka dalam hal ini siswa yang memiliki motivasi tinggi dan siswa yanag memiliki motivasi rendah tidak ada pengaruh dalam proses pembelajaran pada pemahaman konsep siswa. Walaupun tidak ada interaksi antara model pembelajaran dan motivasi, telah dijelaskan bahwa model pembelajaran berpengaruh pada pemahaman konsep siswa.

Model pembelajaran yang digunakan pada penelitian ini yaitu Inkuiri terbimbing dan model pembelajaran langsung. Model pembelajaran Inkuiri terbimbing lebih baik dari model pembelajaran langsung dilihat dari rataan marginal yang menunjukkan bahwa rataan model pembelajaran inkuiri terbimbing lebih besar dari rataan model pembelajaran langsung. Maka dalam penelitian ini model pembelajaran Inkuiri terbimbing lebih efektif pada masing-masing motivasi siswa.

Telah dijelaskan bahwa tidak adanya interaksi antara model pembelajaran dan motivasi siswa berdasarkan hasil yang telah dijelaskan bahwa motivasi yang dimiliki siswa tidak berpengaruh pada pemahaman konsep siswa, walaupun dalam penelitian ini untuk perolehan skor pada motivasi tinggi lebih banyak pada motivasi rendah. Hal ini karena dalam penelitian ini telah dijelaskan bahwa motivasi yang dimiliki siswa dipengaruhi oleh faktorfaktor diluar proses pembelajaran. maka dalam penelitian ini pembelajaran Inkuiri terbimbing lebih efektif pada masing-masing motivasi siswa.

Berdasarkan hasil yang telah dijabarkan motivasi tidak berpengaruh pada pemahaman konsep siswa, model pembelajaran memberikan pengaruh pada pemahaman konsep siswa, tetapi tidak adanya interaksi antara model pembelajaran dan motivasi belajar siswa. Banayak faktor yang mempengaruhi proses pencapaian pemahaman siswa baik dari faktor ekstern maupun intern siswa, selain faktor model pembelajaran yang digunakan, motivasi belajar siswa, serta banyaknya keterbatasan penelitian ini sehingga tidak dapat mengontrol faktorfaktor diluar kegiatan belajar mengajar.

\section{PENUTUP}

\section{Simpulan}

Berdasarkan hasil analisis yang telah dikemukakan, maka dapat ditarik kesimpulan sebagai berikut:

1. Model pembelajaran Inkuiri terbimbing menghasilkan pemahaman konsep lebih baik dibandingkan dengan model pembelajaran langsung. Karena penerapan model pembelajaran berpengaruh pada pemahaman konsep siswa.

2. Motivasi tinggi dan motivasi rendah tidak memberikan pemahaman konsep yang lebih baik. Dalam hal ini motivasi tinggi tidak memberikan pengaruh yang lebih baik dari motivasi rendah.

3. Pada masing-masing tingkatan motivasi tidak memberikan pemahaman yang lebih baik pada model pembelajaran Inkuiri terbimbing dan model pembelajaran langsung lebih efektif pada masing-masing motivasi terhadap pemahaman konsep.

4. Pada masing-masing model pembelajaran tidak memberikan efek pemahaman lebih baik pada siswa yang memiliki motivasi tinggi dan siswa yang memiliki motivasi rendah. Karena model pembelajaran berpengaruh terhadap pemahaman konsep, maka model pembelajaran Inkuiri Terbimbing lebih efektif pada masing-masing motivasi.

\section{Saran}

Pada saat menggunakan model pembelajaran Inkuiri terbimbing hendaknya pada penelitian selanjutnya seorang guru dapat mengatur waktu dengan baik pada saat proses pembelajaran, agar setiap tahapnya bisa terlaksana dengan baik. Bagi calon peneliti selanjutnya sebaiknya pada tidak hanya ditinjau dari motivasi belajar 
saja. Sebaiknya penelitian selanjutnya dapat melakukan peninjauan dari sudut yang lain seperti gaya belajar, minat belajar dan lain sebagainya agar dapat mengetahui faktor-faktor dari pemahaman konsep. Hasil ini juga terbatas pada materi trigonometri sehingga disarankan kepada peneliti selanjutnya untuk mencoba menerapkan model Inkuiri terbimbing pada materi lain dalam mata pelajaran matematika.

\section{DAFTAR PUSTAKA}

Balitbang. (2011). Survey Internasional TIMSS (Trends In International Mathematics and Science Study). [Online] Tersedia pada http//litbang. Kemdikbud.go.id/detail.php? id=214. (diakses pada 4 Januari 2017).

Chodijah, S., dkk. Pengembangan Perangkat Pembelajaran Fisika Menggunakan Model Guided Inquiry yang Dilengkapi Penilaian Portofolio pada Materi Gerak Melingkar.Jurnal Penelitian Pembelajaran Fisika.Vol. 1 (2012) 1 -19

Dahlan, S. A. (2004). Meningkatkan Kemampuan Penalaran dan Pemahaman Siswa SLTP Melalui Pendekatan Pembelajaran Open Ended. Bandung: Disertasi UPI. Tidak diterbitkan.

Dimyati dan Mudjiono. (2013). Belajar dan Pembelajaran. Jakarta: PT Rineka Cipta.

Hamalik, Oemar. (2014). Psikologi Belajar dan Mengajar. Bandung: Sinar Baru Algensindo.

Kurniawati, dkk. 2014. Pengaruh Pembelajaran Inkuiri Terbimbing Integrasi Peer Instruction Terhadap Penguasaan Konsep dan Kemampuan Berpikir Kritis Siswa. Jurnal Pendidikan Fisika Indonesia. 10(1): 36-46.

Lestari, eka karunia dan Yudhanegara, Muhammad Ridwan. (2015). Penelitian Pendidikan Matematika (panduan praktid menyusun skripsi, tesis, dan karya ilmiah dengan pendekatan kuantitatif, kualitatif, dan kombinasi disertai dengan model pembelajaran dan kemampuan matematis). Bandung : PT Refika Adimata.

Putra, Ida Bagus Soma. (2012). "Pengaruh Pembelajaran Inkuiri dan Motivasi Belajar terhadap Pemahaman Konsep IPA". Jurnal penelitian pasca sarjana undiksha. 1, (1), 1-10.
Sugiyono. (2015). Metode Penelitian Pendidikan Pendekatan Kuantitatif, Kualitatif, dan $R \& D$. Bandung: Alfabeta.

Suryabrata, Sumadi (2012). Psikologi Pendidikan. Jakarta: Rajawali Pers.

Sutikno, Sobry. (2014). Metode dan Model Pembelajaran. Lombok: Holistica

Trisnanto. (2009). Pengaruh Media Terhadap Belajar Anatomi Ditinjau Dari Motivasi Siswa. Skripsi. Universitas Negeri Surakarta. Surakarta Tidak Diterbitkan.

Wahyudin \& Sutikno. Keefektifan Pembelajaran Berbantuan Multimedia Menggunakan Metode Inkuiri Terbimbing Untuk Meningkatkan Minat dan Pemahaman Siswa. Jurnal Pendidikan Fisika Indonesia Vol. 6 (2010) 58 -62. 